\title{
DIAGNÓSTICO Y TRATAMIENTO DEL TERCER MOLAR RETENIDO
}

Pablo Miers NUÑEZ

Desde su formación hasta su colocación definitiva en la arcada los terceros molares en Cirugía Oral son de gran interés, por su frecuencia, por su variedad de presentación y complicaciones que frecuentemente desencadenan, da lugar a una serie de accidentes que condicionan una verdadera patología de interés para el odontólogo cirujano. La difícil previsibilidad en la erupción dentaria de los terceros molares a las entidades terapéuticas, antes los casos asintomáticos y la influencia sobre determinadas complicaciones mecánicas, fundamentalmente sobre el apiñamiento de los incisivos inferiores, lesión del diente vecino y complicaciones patológicas del hueso mandibular. Para el diagnóstico y tratamiento de los terceros molares el Odontólogo cirujano debe considerar varios aspectos como: estado general del paciente, características anatómicas, manifestaciones clínicas, valoración de imágenes y actitud conservadora o quirúrgica para lograr los mejores resultados. 